\title{
APPARENT DICHOTOMIES, COVERT SIMILARITIES: A RESPONSE TO JOOST PAUWELYN
}

\author{
Catherine A. Rogers*
}

In his thoughtful article, ${ }^{1}$ Joost Pauwelyn poses a perplexing question: How can it be that trade and investment are converging in their substantive "legal orders," but diverging in terms of perceived legitimacy? InvestorState Dispute Settlement (ISDS), he argues, is in a "state of crisis" whereas World Trade Organization (WTO) dispute settlement is generally regarded as "successful." Pauwelyn's provocative and counter-intuitive explanation for this paradox focuses on the apparent differences between the pool of decision-makers in each regime: WTO disputes are resolved by nameless, faceless, panel-inexperienced bureaucrats who often lack legal training, whereas "investment arbitrators are typically high-powered, elite jurists" with more expertise and experience than their WTO counterparts. ${ }^{2}$

From this starting premise, Pauwelyn offers the (for some) appealing hypothesis that international legal regimes might be more effective and successful without lawyers - a rule of law without lawyers! For those who revel in lawyer jokes, this thesis may seem like a fantastic punch-line. But deeper investigation of the underlying data and structures of WTO dispute resolution and ISDS suggests we should not yet kill all the lawyers.

In this essay, I challenge some of Pauwelyn's characterizations of WTO and ISDS decision-making and his related conclusions. I then offer alternative possible explanations for the legitimacy gap between WTO and ISDS decision-making, and conclude with some reasons why lawyers and legal expertise are essential attributes for the adjudicators we entrust with development of an international rule of law.

\section{How Different Is Different?}

Pauwelyn's title and rhetoric focus on the identity of international adjudicators, but the text of the article seeks to advance the larger thesis. Pauwelyn argues that when the political salience of a legal field (like investment or trade) increases, and countries face reduced options for defection from adjudicatory apparatus, "representativeness, inclusiveness and trust by governments and other stakeholders" are key to perceived legitimacy. ${ }^{3}$ Pauwelyn concludes that W'TO dispute resolution outstrips ISDS on each of these, but the bases for his conclusions are worth reexamination.

* Visiting Fellow, PluriCourts, Center for Excellence, University of Oslo; Professor of Law, Penn State Law and Queen Mary, University of London. For their thoughtful comments, I am indebted to Chris Drabozal, Ole Kristian Fauchald, Mark. Kantor, and Daniel Behn.

Originally published online 13 April 2016.

${ }^{1}$ Joost Pauwelyn, The Rule of Law Without the Rule of Lawyers? Why Investment Arbitrators Are from Mars, Trade Adjudicators from Venus, 109 AJIL 761 (2015).

${ }^{2}$ Id. at 763 .

${ }^{3} \underline{I d}$. at 764 . 
Representativeness and Inclusiveness

Some of Pauwelyn's most damning assessments of ISDS relate to the admittedly closed, interlocking, and shockingly small group of ISDS arbitrators who dominate appointments and lack any measure of meaningful diversity. As he points out, a 2012 study found that a cozy group of ten arbitrators get twenty percent of all appointments, with one arbitrator receiving a full 3.4 percent. ${ }^{4}$ Relying on work by Sergio Puig, ${ }^{5}$ Pauwelyn notes that close to one-third of all ISDS appointments go to arbitrators from the United States, France, and the United Kingdom. He then uses various metrics to compare this closed, nondiverse network to decision-makers in the WTO context. ${ }^{6}$

In this comparison, Pauwelyn finds that on WTO panels, only a few individuals are frequently (more than ten times) reappointed, and those individuals preside in only a small percentage of the cases (less than 15 percent). Perhaps more striking, of the top fifteen most-appointed WTO panelists, nine are from developing countries and four are women. ${ }^{7}$ These W'TO numbers seem to make ISDS's lack of diversity all the more embarrassing. Until you scratch just below the surface of the data.

\section{The dark side of limited reappointments}

Limited reappointments in WTO panels have the beneficial side-effect of increasing the pool of decisionmakers, but Pauwelyn's sunny hypothesis misses a darker side revealed by insider commentary. Instead of pursuing unvarnished neutrality, insiders describe the appointment process as highly strategic and politicized. A former WTO Deputy Director-General describes panel appointment as a "tactical game with perverse incentives," while another W'TO veteran describes how parties "confront a 'prisoner's dilemma' type situation." Meanwhile, instead of a willingness to forego expertise, some predict that the WTO will "inevitably evolve towards having a roster of permanent Panelists."10

Moving to the Appellate Body (AB) level, Manfred Elsig and Mark Pollack also identify a darker side to limited reappointments: "[F]ailure to re-nominate a member is testament to growing politicization of the WTO judicial appointment process, and a sign that the nomination process can potentially be ... an expost warning to sitting members about independence from the governments that nominated them." ${ }^{11}$ In other words, AB members are refused reappointment to punish them for failing to support adequately their appointing government's views.

Ironically, since we are discussing legitimacy, Elsig and Pollack argue the increased politicization in AB member selection was triggered by a protransparency decision. In 1998, the AB announced a procedure allowing submissions of amici briefs from nongovernmental organizations. Many states were reportedly "furious" over the decision, which was characterized as "trespassing its own mandate and becoming a legislature."12

${ }^{4} \underline{I d}$. at 777 .

5 Sergio Puig, Social Capital in the Arbitration Market, 25 Eur. J. INT’L L. 387 (2014).

${ }^{6}$ Pauwelyn, supra note 1 , at 768-783.

${ }^{7} \underline{I d}$. at 77 .

${ }^{8}$ Alejandro Jara, The Legal Affairs Division at thirty and beyond, in A HisTORY OF LAW AND LAWYERS IN THE WTO 604 (Gabrielle Marceau ed., 2016).

${ }_{9}^{9}$ Reto Malacrida, WTO Panel Composition: Searching Far and Wide for Administrators of World Trade Justice, in A HISTORY OF LAW AND LAWYERS IN THE WTO 311, 313 (Gabrielle Marceau ed., 2016).

10 See Jara, supra note 8 , at 612 .

11 Manfred Elsig \& Mark A. Pollack, Agents, Trustees, and International Courts: The Politics of Judicial Appointments at the World Trade Organization, 20 EUR. J. INT'L REL. 391, 404 (2014).

$12 \underline{I d}$. at 405 . 


\section{The "know-nothings" know something}

Pauwelyn lauds the fact that WTO appointment processes seem to "exclude individuals with outspoken views or track records in favor of either trade or trade protectionism." 13 Noting that "disclosed preferences lead to fewer, rather than more appointments," Pauwelyn suggests that this phenomenon implies that states engage in an apolitical process to identify truly neutral WTO decision-makers. ${ }^{14}$

His characterization certainly does not apply in the AB. Elsig and Pollack describe the AB vetting process as a don't-ask-don't-tell game aimed at sublimating candidate's views, not ensuring that they are neutral. "States limited their support to candidates whose views were not too distant from their own," 15 and in response, $A B$ candidates began to strategically conceal their "views on hot-button issues of interest" as they progressed through a "gauntlet of ambassadorial interviews." 16 To avoid being nixed, candidates were intensely coached to avoid saying anything that might be at odds with a state's views and to "give selective information to the nominating principals." 17

Under this view, lack of professional publications does not signal neutrality, but shrewdness in playing the hyperpoliticized $\mathrm{AB}$ appointment game. Elsig and Pollack go so far as to analogize politicization of the $\mathrm{AB}$ appointment process to politicization of the process for appointing Supreme Court Justices in the United States ${ }^{18}$ — not a flattering proposition given the circus Senate approval proceedings have become.

\section{The Secretariat shellgame}

The power and composition of the Secretariat are essential to understanding the extent of legal expertise in W'TO decision-making. In making his case for "rule of law without lawyers," Pauwelyn explains that the WTO Secretariat alleviates the need for lawyers by playing an "important role in the preparation, deliberation, and drafting of panel reports." ${ }^{19}$ Put more plainly, WTO decision-making is not undertaken without legal expertise, but with legal expertise discreetly outsourced to a largely invisible and nontransparent Secretariat.

Some scholars posit that "being 'invisible' may enhance [the Secretariat's] potential" for "hugely unrecognized influence" 20 and allow it to exercise "invisible governance." 21 This influence is amplified by the Secretariat's considerable control over who gets appointed to panels. Even Pauwelyn contemplates that the Secretariat has disincentives to appoint experts or "star adjudicators," who might be less deferential to Secretariat guidance. ${ }^{22}$ If these characterizations are accurate, diversity and repeat appointments at the Secretariat call for consideration in assessing the expertise, diversity, and inclusiveness in WTO decision-making.

\footnotetext{
13 Pauwelyn, supra note 1 , at 787.

${ }^{14} \underline{I d}$.

${ }^{15}$ Elsig \& Pollack, supra note 11, at 407.

${ }^{16} \underline{I d}$. at 410 .

$17 \underline{I d}$. at 407 .

${ }^{18} \underline{I d}$.

19 Pauwelyn, supra note 1 , at 795.

20 Jarle Trondall et al., UnPacking International Organizations: The Dynamics of Compound Bureaucracies 99 (2010).

${ }^{21} \underline{I d}$. at 97 .

22 Pauwelyn, supra note 1, at 796; see also, Petros C. Mavroidis, Arbitrating Trade Disputes: Who's the Boss?, 23 ArB. INT'L 481 (2012) (In appointing, the Secretariat's "incentive remains the same: the stronger the Panelists, the weaker the position of the Secretariat throughout the process.").
} 


\section{Homogeneity in the control center}

WTO panelists may be more widely representative of WTO membership, but the WTO Secretariat has a decidedly different composition. Members of the WTO Secretariat have relatively long tenure compared not only with WTO decision-makers, but even with other international bureaucracies. ${ }^{23}$ And who could blame the WTO for this? WTO law is consistently described as dense, intricate, and even byzantine. What sense would it make to systematically replace knowledgeable Secretariat members with novices who require years to catch up to their ousted predecessors?

Meanwhile, the Secretariat comprises mainly (roughly two-thirds) individuals from North America and Europe. ${ }^{24}$ And most of those working in the Legal Affairs and Rules Divisions of the Secretariat, the main divisions that assist dispute resolution panels, are (surprise!) lawyers. ${ }^{25}$

All this is not to deny or discount the serious diversity problems in ISDS and the need to fix those problems. But it does raise questions about whether the WTO approach offers a meaningful alternative to ISDS's lack of diversity. More fundamentally, it raises doubts about the viability of complex legal decision-making in the absence of experienced legal experts.

The WTO appears to have already intuited the need for more legal expertise. As Pauwelyn notes, only three of twenty-five $\mathrm{AB}$ members have lacked a law degree, and the percentage of WTO panelists with legal backgrounds has been slowly increasing. In recent years, virtually every panel has at least one lawyer on it. José Augusto Fontoura Costa argues that "the growth of the share of panelists with a legal background may be a reaction to the prevalence of appeals and the need to comply with the AB's standards." 26 Trends in panel composition thus implicitly acknowledge that the factual and legal complexity of WTO decision-making requires some legal expertise.

\section{"Trust" versus "Control"}

Beyond diversity and inclusiveness, Pauwelyn argues that state "trust" or "voice" are necessary for a regime to be legitimate. But instead of describing trust in the WTO, he argues that the WTO dispute settlement may be successful because it allows for "cautious control" by governments, leaves room for resolution through settlement instead of "rule compliance," and is not overly "ambitious." 27

ISDS arguably provides more constructive forms of voice that reify adjudicatory apparatus, rather than rely on weakened versions. Take the new-ish China-Canada Bilateral Investment Treaty (BIT). ${ }^{28}$ It includes specific requirements that arbitrators have "expertise or experience in public international law, international trade or international investment rules, or the resolution of disputes arising under international trade or international investment agreements." Meanwhile, this language reaffirms states' interest in legally trained expert decisionmakers. The requirement of public international law expertise seeks to ensure that public law perspectives, which states and critics argue have been lacking, are duly represented in ISDS tribunals.

\footnotetext{
23 Pauwelyn, supra note 1 , at 796.

${ }^{24}$ These statistics are for the entire Secretariat, not only the Legal Affairs and Rules Divisions.

${ }^{25}$ Apparently, no separate breakdown of nationalities is available for the Legal Affairs and Rules Divisions.

${ }^{26}$ José Augusto Fontoura Costa, Comparing WTO Panelists and ICSID Arbitrators: The Creation of International Legal Fields, 1(4) Oñati Socio-Legal Series 23 (2011).

${ }^{27}$ Pauwelyn, supra note 1 , at 802.

${ }^{28}$ Global Affairs Canada, Agreement Between the Government of Canada and the People's Republic of China for the Promotion and Reciprocal Protection of Investments, GOVERNMENT OF CANADA (2014).
} 
States also exercise voice by revising BITs to take account of the substance of investment arbitration decisions. In some instances, states codify analysis in arbitral awards to fill gaps in vaguely worded treaties. In other instances, they reject reasoning from arbitral awards. For example, in their BIT, China and Canada reject ISDSdeveloped definitions of "most favored nation treatment" and "denial of benefits." Even these rejections, however, evidence an iterative process in which expert arbitrators aid in the development of investment law by forcing states to adopt more precise language. ${ }^{29}$

Another potential form of voice is the emerging practice of joint government interpretations of investment treaties being developed by the Organisation for Economic Co-operation and Development. ${ }^{30}$ If successful, such joint interpretations would provide guidance for tribunals in interpreting treaty language consistent with state intentions.

One final, but important, state exercise of voice in ISDS takes us back to the heart of Pauwelyn's article. States frequently reappoint the arbitrators they regard as more state-oriented. This practice is criticized by Pauwelyn as contributing to the closed circle of arbitrators. ${ }^{31}$ Its overall aim, however, is largely analogous to the WTO appointment process that ensures panelists, whose selection states work hard to engineer, and in a more diffuse way AB members, who are adherent to states' views. Having states directly choose "their arbitrator" permits states to affect the composition of the tribunal, without controlling it, much-intensified but to this extent comparable to the use of ad hoc judges at the International Court of Justice. Allowing preferences without facilitating control arguably produces a more legitimate balance than the W'TO appointment process described above.

If, as argued above, ISDS does not suffer dramatically in comparison with the WTO on the three markers identified by Pauwelyn (representativeness, inclusiveness, and voice), the question remains: What does account for the apparent gap in perceptions of the relative legitimacy between the two?

\section{Big Dollars and Despised Parties}

Before turning to his primary thesis about the decision-makers, Pauwelyn offers a number of possible alternative explanations that may account for ISDS's legitimacy crisis. ${ }^{32}$ None of these criticisms, however, are unique to ISDS. They are effectively recycled versions of criticisms that were originally leveled against the WTO and its decision-makers.

In terms almost identical to Pauwelyn's, critics of the WTO in the 1990s claimed that its decisions could force changes in national social and economic policies, ${ }^{33}$ that the WTO was unduly biased in favor of multinational corporations, ${ }^{34}$ that its processes were antidemocratic, ${ }^{35}$ biased against developing states, ${ }^{36}$ nontransparent, and unaccountable. ${ }^{37}$

29 This analysis was presented by Christopher Thomas in his keynote speech at the $4^{\text {th }}$ Annual Asia Pacific ADR Festival in Seoul, Korea (2015).

${ }^{30}$ David Gaukrodger, Loint government interpretation of investment treaties, OECD INSIGHTS (Feb. 15, 2016).

${ }^{31}$ Pauwelyn, supra note 1 , at 803 .

$32 \underline{I d}$. at 762 .

33 Global Exchange, Top Reasons to Oppose the WTO.

34 Peter Constantini, What's wrong with the WTO? (2001).

35 David C. Korten, WTO Is Anti-Democratic, Anti-People, and Anti-Environment, Yes! MAGAZINE, Nov. 30, 1999.

36 Aurelie Walker, The WTO has failed developing nations, GuARDiAn, Nov. 14, 2011.

37 Shefali Sharma, WTO Decision Making: A Broken Process, Institute fOr Agriculture ANd Trade Policy WTO CANCUN SERIES PAPER No. 4 (2003). 
More recently, attacks on the WTO have become more muffled. Rather than approval of the WTO, however, the quieting of WTO criticisms may just signal that ISDS has become the new totem for antiglobalization angst. Is there some reason, other than the identity of the decision-makers, why ISDS presents a more appealing target than WTO dispute resolution? Two possibilities come to mind, neither of which made Pauwelyn's list: 1) the identity of the parties in ISDS, and 2) the nature of the relief.

The WTO has been accused of favoring corporate interests, but in ISDS the corporate interests are personified in the corporate claimants, and foreign ones at that. Foreign investors are frequently scapegoated, hence the need for foreign investment protection in the first place.

ISDS remedies are also more inflammatory than WTO remedies. When the WTO finds a state policy violates international trade law, the typical outcomes are an order to discontinue or countermeasures. In most cases, these outcomes are difficult to distill into incendiary headlines.

By contrast, when foreign corporations prevail in ISDS, most often the remedy is - CA-CHING! —a multimillion or multibillion dollar award. News reports of huge sums flowing from a state's coffers to a foreign investor read like a virtual pick-pocketing of tax revenues collected from a state's citizenry. And the pickpocket is, of course, an elite arbitrator. Resentment, in other words, may not be because of their expertise per se, but because the arbitrators facilitate sensational outcomes that—regardless of their propriety under applicable investment law — are bound to disturb a domestic citizenry.

If the identity of claimants and nature of remedies account for the disparate reactions to WTO dispute settlement in comparison with ISDS, could the relative success and effectiveness of each be evaluated independently of these variables?

Recent events have given an excellent opportunity for a thought experiment. Australia's plain packaging tobacco legislation has been challenged both through ISDS and in the WTO. ${ }^{38}$ Recently, the ISDS claim was dismissed for lack of jurisdiction, but not before it was denounced in scathing terms and cited as the primary reason for Australian reluctance to conclude investment treaties with ISDS provisions. The WTO claims, meanwhile, are still pending. They have to date received relatively scant attention in the press. They certainly have not prompted calls for Australia's withdrawal from the WTO.

Would a decision in favor of the interests of a tobacco company issued by WTO-style adjudicators be insulated from the backlash brought on by the mere possibility of such a ruling by ISDS arbitrators? Or would a decision in favor of a tobacco company simply refocus criticism back to WTO-style dispute resolution? Or perhaps, more appropriately, back on the substance of trade and investment law and their potential to override national health and safety regulations?

One thing does already seem clear. In advocating a "WTO-style court," the European Union does not want diplomats without legal training as decision-makers. The EU-Canada CETA provides for a WTO-style court, but Article 8.27 specifies that members shall possess:

[T] he qualifications required in their respective countries for appointment to judicial office, or be jurists of recognized competence ... [and] have demonstrated expertise in public international law. It is desirable that they have expertise . . . in international investment law, in international trade law and in the resolution of disputes arising under international investment or international trade agreements. ${ }^{39}$

\footnotetext{
${ }^{38}$ Claims based on plain packaging legislation are also pending in other fora, and the legislation is not always faring well-in the United Kingdom, similar legislation was struck down by Lord Hoffman as unlawful and violative of EU law. See Trevor Little, $\underline{\text { Plain }}$ packaging battle escalates as WTO prepares for hearings on challenges to Australian regime, WORLD TRADEMARK REVIEW, May $26,2015$.

${ }^{39}$ Comprehensive Economic and Trade Agreement (CETA) between Canada, of the One Part, and the European Union, of the Other Part art. 8.27.
} 
This new court may now be regarded as a potential remedy for ISDS's primary affliction: ad hoc arbitrators who have insufficient knowledge of public international law. But query what might happen if it were to make a large monetary award to a tobacco company for the plain packaging legislation promised in Canada's new Prime Minister's campaign? ${ }^{40}$

\section{Facts, Expertise, and Adjudication}

Some of adjudicators' most important functions are exercised between appointment and outcomes: factfinding and procedural case management. "In important cases, the problem [with fact-finding] is not merely one of ferreting out facts but identifying those that are both relevant and significant-a process entailing valueladen assumptions which determine criteria of discrimination." ${ }^{41}$ This process is what legal education trains lawyers to do.

International adjudication presents special challenges for fact-finding. Typically the applicable rules are stark and say nothing about such important topics as the appropriate balance between costs and benefits in evidence gathering, the permissible procedures for gathering evidence, the admissibility or weight of various types of evidence, standards of proof, and the like. Decisions on these essential issues quickly become messy in international and cross-cultural settings because they implicate conflicting value-laden cultural assumptions held by the different parties.

For all the laurels heaped on WTO dispute resolution, it is often criticized, along with other public international law tribunals, ${ }^{42}$ for poor fact-finding. WTO panels are often left to rely exclusively on materials voluntarily submitted by the parties, and are too weak to persuade or compel them to produce additional materials. ${ }^{43}$ For these reasons, at least one commentator has proposed structural reform to create a specialized fact-finding body at the WTO.44

In international commercial arbitration, by contrast, years of experience and trial and error have resulted in shared understandings and time-tested approaches to effective case management and fact-finding. These complex and sophisticated techniques have now been successfully imported into ISDS.

At the W'TO, the increasing importance of complex fact-finding in international disputes may require a nudging upwards of the current one-lawyer-per-panel number on WTO panels. Meanwhile, it seems that one of ISDS's supposed liabilities - that most arbitrators come from private practice in commercial cases-may come to be regarded as an important asset.

\section{Conclusion}

Comparative institutional analysis is a valuable tool for understanding, evaluating, and improving our international courts. But the metrics we use to compare can portend the outcomes of comparison. In a comparison of chalk with cheese on the basis of legibility, chalk comes out on top. But with respect to their edibility, most people would pick the cheese.

${ }^{40}$ Garfield Mahood, Liberals can belp stub out smoking epidemic, STAR, Jan. 18, 2016.

${ }^{41}$ Hardy Dillard, A Tribute to Pbillip C. Jessup and Some Comments on International Adjudication, 62 CoLum. L. REv. 1138 (1962) (this citation and related observations are borrowed from the insightful work, John R. Crook, Fact-finding in the Fog: Determining the Facts of Upheavals and Wars in Inter-State Disputes, in The Future of InVESTMENT Arbitration (Catherine A. Rogers \& Roger P. Alford, eds. 2009)).

42 See Pulp Mills on the River Uruguay (Arg. v. Uru.), Dissenting Opinion of Judge ad hoc Vinuesa, 2010 ICJ ReP. 147 (Apr. 20 ).

${ }^{43}$ David Collins, Institutionalized Fact-Finding at the WTO, 27 J. INT'L L. 367, 370 (2006) (noting a "tendency for governments to ignore panel requests for facts.").

44 See id. 
Inexperienced bureaucrats have not drawn the public outrage that investment arbitrators have, but they exist only by outsourcing legal and fact-finding support to a strong Secretariat and in an institutional structure that apparently thrives because its aspirations "are not overly ambitious." 45 For those of us who support development of an international rule of law, and see robust international tribunals as an essential feature, the lawyers who serve as expert, elite adjudicators are not expendable.

45 Pauwelyn, supra note 1 , at 802 . 